\title{
Corporate Governance and Earnings Quality: Students Perception in Indonesia
}

\author{
Wiwik Utami ${ }^{1}$, Dwi Asih Surjandari ${ }^{2}$, Taufik Akbar ${ }^{3}$ \\ \{wiwik.utami@mercubuana.ac.id ${ }^{1}$,dwi.asih@mercubuana.ac.id ${ }^{2}$, \\ taufik.akbar@mercubuana.ac.id ${ }^{3}$ \}
}

Universitas Sangga Buana, Indonesia ${ }^{1}$, Universitas Mercu Buana, Indonesia ${ }^{2}$, Universitas Sangga Buana, Indonesia ${ }^{3}$

\begin{abstract}
This study aims to examine students' understanding of corporate governance and its relationship to earnings quality. Some of Business programs (Accounting, Management, Business Administration) in Indonesia have integrated issues regarding corporate governance in the curriculum. The population are students of the Undergraduate and Postgraduate business programs in Indonesia. Sampling method is area random sampling based on province in Indonesia. Total participants are 278 came from Aceh, Jakarta, Bandung, Yogyakarta, Surabaya, Pontianak, Menado, Makasar. The results reveal that, students perception on strong commissioners will generate high earnings quality, as well as strong audit committee. The activities of commissioners in well-scheduled, high frequency of meetings and attendance are perceived in line with high earnings quality. Bachelor degree and master degree had similar perception on earnings quality based on commissioners and audit committees but diference perception based on activities meeting.
\end{abstract}

Keywords: Corporate Governance, Earning Quality, Students Perception.

\section{Pendahuluan}

Tata kelola perusahaan mulai popular diperbincangkan di Indonesia sejak terjadinya peristiwa krisis ekonomi pada tahun 1998. Kecurangan akuntansi pada perusahaan perusahaan besar telah membawa dampak yang luar biasa bagi ekonomi dunia. Dorongan untuk menerapkan tata kelola perusahaan yang baik (good coporate governance) berasal dari permintaan International Monetary Fund (IMF) kepada Pemerintah Indonesia. Permintaan tersebut terkait dengan dana pinjaman yang akan diberikan oleh IMF kepada Pemerintah Indonesia.

Sebagai respon permintaan IMF tersebut pemerintah mengeluarkan berbagai regulasi terkait dengan tata kelola Badan Usaha Milik Negara (BUMN) dan juga regulasi pasar modal. Regulasi tersebut terkait dengan struktur tata kelola dan proses tata kelola. Secara spesifik disebutkan bahwa emiten yang tercatat di Bursa Efek Indonesia wajib mengangkat komisaris independen dan membentuk komite audit. Peran komisaris Independen dan komite audit dinilai penting sebagai kontrol terhadap kebijakan manajemen.

Sejalan dengan kebutuhan dunia usaha dan pemerintah terkait dengan isu tata kelola maka dunia pendidikan melakukan kajian untuk memasukkan pengetahuan tata kelola perusahaan 
dalam materi ajar. Beberapa perguruan tinggi mengambil kebijakan untuk mengintegrasikan isu tata kelola pada mata kuliah tertentu, missal pada matakuliah Etika Bisnis dan Audit, tapi terdapat juga program studi yang menjadikan kajian tata kelola perusahaan sebagai mata kuliah yang mandiri dengan memberikan bobot 3 satuan kredit semester (SKS).

Kurikulum di Indonesia dirancang sesuai dengan Kerangka Kualifikasi Nasional Indonesia berdasarkan pada Undang undang No. 8 tahun 2012. Implikasi KKNI adalah adanya pedoman yang dapat digunakan oleh perguruan tinggi terkait dengan:

a. Penataan jenis dan strata pendidikan

b. Penyetaraan mutu lulusan

c. Pengembangan Sistem Penjaminan Mutu

d. Pengembangan kurikulum

e. Memfasilitasi pendidikan sepanjang hayat

Di samping KKNI terdapat peraturan yang lain yang digunakan sebagai pedoman dalam perancangan pembelajaran yaitu Peraturan Menteri Riset Teknologi dan Pendidikan Tinggi Nomor 44 Tahun 2015. Pada pasal 8 peraturan tersebut dijelaskan tentang kriteria minimal tingkat kedalaman dan keluasan materi pembelajaran yang dituangkan dalam kurikulum, yang harus diikuti oleh peserta didik pada program studi di perguruan tinggi.

Sejalan dengan KKNI dan Permenristek No, 44 tahun 2015 maka masing masing bidang ilmu mengadakan seminar, workshop dan symposium untuk merumuskan profil lulusan, kompetensi dan kurikulum yang sesuai dengan kebutuhan para pemangku kepentingan. Program studi akuntansi dan program studi bisnis di Indonesia membuat rumusan profil dan kompetensi minimal yang harus diraih oleh lulusan Perguaruan tinggi. Tidak ada regulasi yang mengharuskan memasukkan materi tata kelola peusahaan dalam kurikulum pendidikan bisnis di Perguruan Tinggi.

Program studi akuntansi dan bisnis memasukkan isu tata kelola perusahaan menjadi salah satu isu baru yang dirancang dalam materi pembelajaran. Meski dalam perancangan materi pembelajaran masih sangat beragam karena masih terbatasnya referensi. Penelitian ini bertujuan untuk menjawab pertanyaan penelitian sebagai berikut: (1) apakah mahasiswa mampu membedakan tata kelola yang baik sesuai dengan regulasi dengan tata kelola yang tidak baik, (2) apakah mahasiswa memberikan penilaian kualitas laba yang lebih tinggi pada perusahaan yang memiliki tata kelola yang baik dan sebaliknya (3) apakah terdapat perbedaan penilaian yang diberikan oleh mahasiswa Strata 1 dan Magister.

\section{Kajian Pustaka dan Hipotesis}

\subsection{Teori Keagenan dan Tata kelola perusahaan}

Teori keagenenan (agency theory) menjelaskan bahwa terdapat hubungan keagenan antara pemilik perusahaan (investor) dan pengelola perusahaan (manajemen). Kedua pihak mempunyai tujuan yang sama yaitu meningkatkan nilai perusahaan. Namun dalam praktek bisnis tidak semua kebijakan manajemen sejalan dengan kepentingan pemilik. Manajemen menguasai informasi sehingga mempunyai peluang untuk mengambil keputusan yang lebih berpihak pada kesejahteraan dirinya, dan mengabaikan kesejahteraan pemilik. Biaya yang timbul untuk mengontrol manajemen agar sejalan dengan kepentingan manajemen dikenal dengan istilah biaya keagenan (agency cost). 
Tata kelola perusahaan (corporate governance) merupakan suatu sistem yang bertujuan untuk melindungi para pemangku kepentingan (stakeholder) dari potensi perilaku oportunistik manajemen (teori keagenan). Manajemen menguasai informasi operasional dan keuangan perusahaan, disisi lain para pemangku kepentingan eksternal memiliki akses yang sangat terbatas. Solomon dan Solomon (2014)(1) menyatakan bahwa good corporate governance adalah suatu sistem checks and balances, baik internal maupun eksternal yang menjamin bahwa perusahaan melaksanakan akuntabilitas kepada seluruh stakeholders, dan bertanggung jawab secara sosial dalam aktivitas bisnisnya. Tata kelola perusahaan digunakan sebagai mekanisme dalam mengontrol dan mengawasi kinerja manajemen untuk mencapai tujuan perusahaan dan kepentingan pemilik saham.

Efektivitas GCG dalam mengawasi proses pelaporan keuangan merupakan sarana utuk menjaga kepercayaan investor di pasar modal. Mekanisme GCG yang baik diharapkan dapat meningkatkan kualitas laba. Chang dan Sun (2010)(2) menemukan bahwa penilaian pasar terhadap kualitas laba secara signifikan lebih tinggi untuk perusahaan-perusahaan yang mengungkapkan fungsi GCG yang lebih kuat. Holder dan Sharma (2010)(3) menyimpulkan bahwa persepsi kreditur dalam memberikan keputusan kredit sangat memperhatikan professional dan kekuatan direksi.

Chaghadari (2011)(4) mengkaji mengenai corporate governance yang diwakili oleh empat karakteristik yaitu independensi dewan, dualisme CEO, struktur kepemilikan dan ukuran dewan dan pengaruhnya terhadap kinerja perusahaan. Kinerja perusahaan diukur dengan return on asset perusahaan public di pasar modal Malaysia menyimpulakan bahwa dualisme CEO memiliki hubungan negatif dengan kinerja perusahaan dan tidak ada pengaruh signifikan independensi dewan, ukuran dewan dan struktur kepemilikan terhadap kinerja perusahaan. Dewan komisaris mempunyai peran penting di dalam pengendalian perusahaan. Berbagai kasus manipulasi dan kebangkrutan akibat rendahnya Good Corporate Governance dapat disebabkan karena dewan komisaris yang tidak kompeten dan tidak independen (SarbanasOxley Act 2002)(5).

\subsection{Kualitas Laba dan Tata Kelola perusahaan}

Kualitas laba (earnings quality) adalah merupakan laba yang mencerminkan kinerja perusahaan yang sesuai dengan realitas ekonomi, terbebas dari pengaruh diskresioner manajemen. Manajemen mempunyai kepentingan jangka pendek untuk dapat menunjukkan kinerja yang terbaik. Manajemen sadar bahwa angka laba digunakan oleh berbagai pihak untuk pengambilan keputusan. Oleh karena itu manajemen akan menggunakan wewenangnya untuk memilih atau membuat kebijakan tertentu agar angka laba dapat dikelola atau diatur sesuai kepentingan manajemen atau popular dikenal dengan manajemen laba (earnings management). Hashima \& Devi (2012)(6) and Kamarudin et.al (2012)(7) melakukan kajian tentang hubungan tata kelola perusahaan yang baik dengan kualitas laba dan menyimpulkan bahwa kualitas tata kelola yang diproksi dengan kualitas CEO berpengaruh signifikan positip terhadap kualitas laba. Hasil yang berbeda diungkapkan oleh Gaio \& Raposo (2014)(8) yang menyimpulkan ada hubungan negative anatara peringkat GCG dengan peringkat kualitas laba.

Cohen et.al (2004)(9) mengungkapkan bahwa mekanisme GCG yang baik akan meningkatkan kualitas laba yang dilaporkan. Abbadi. et.al (2016)(10) mengkaji hubungan antara mekanisme GCG dengan kualitas laba akuntansi di perusahaan perusahaan Kanada, menyimpulkan bahwa kualitas tata kelola berhubungan negatif dengan laba akrual abnormal. Hal ini bermakna bahwa semakin tinggi kualitas GCG maka semakin kecil tingkat laba akrual 
abnormal. Laba abnormal akrual yang rendah mencermin kualitas laba laba yang tinggi. Besaran abnormal akrual berhubungan negatip dengan independensi anggota dewan, dan keselarasan antara kompesensi manajemen dengan hak hak pemilik. Shank et. al (2013)(11) melakukan riset dengan menggunakan sample perusahaan Amerika. GCG diukur dengan komponen struktur dan mekanisme GCG yang komprehensif mengacu pada pemeringkatan yang diberikan oleh Institutional Shareholder Services (ISS). Hasilnya menyimpulkan bahwa GCG yang diterapkan oleh perusahaan dengan kapitalisasi kecil memberikan dampak yang signifikan pada peningkatan kinerja dan imbal hasil saham pada semua periode pengamatan 10 tahun.

\subsection{Hipotesis}

Regulasi pasar modal Indonesia dan Otoritas Jasa keuangan banyak mengatur tentang Komisaris, Komisaris Independen dan Komite audit. Peneliti menggunakan proksi kualitas tata kelola berdasarkan karakteristik komisaris, komisaris independen dan komite audit. Mengacu pada teori, konsep dan hasil riset terdahulu maka hipotesis penelitiaan adalah ssebagai berikut:

H1: Independensi dewan komisaris yang kuat memiliki kualitas laba yang

lebih tinggi dibandingkan dengan independensi dewan komisaris yang lemah

$\mathrm{H} 2$ : Independensi komite audit yang kuat memiliki kualitas laba yang lebih tinggi dibandingkan dengan independensi komite audit yang lemah

H3: Komisrais utama yang berasal dari komisaris independen memiliki kualitas laba yang lebih tinggi dibandingkan dengan komisaris utama berasal dari dalam perusahaan (pendiri atau keluarga).

H4: Aktivitas komisaris dan komite audit yang terjadwal memiliki kualitas laba yang lebih tinggi dibandingkan dengan yang tidak memiliki aktivitas terjadwal.

H5: Tingkat kehadiran komisaris yang tinggi dalam rapat memiliki kualitas laba yang lebih tinggi dibandingkan dengan yang rendah tingkat kehadirannya.

H6: Frekuensi rapat dewan komisaris yang lebih banyak memiliki kualitas laba yang lebih tinggi dibandingkan dengan frekuensi rapat dewan komisaris yang lebih sedikit

H7: Komisaris independen yang berlatar belakang pendidikan bisnis lebih berorientasi pada kualitas laba dibandingkan dengan komisaris independen yang berlatar belakang pendidikan non bisnis.

H8: Proporsi dewan komisaris yang memiliki latar belakang bisnis yang relative tinggi lebih berorientasi pada kualitas laba dibandingkan dengan proporsi dewan komisaris yang berlatar belakang pendidikan non bisnis.

H9: Komite audit yang lebih berpengalaman dibidang bisnis lebih tinggi kualitas laba dibandingkan dengan komite audit yang belum berpengalaman

H10: Komite audit yang memiliki latar belakang pendidikan bisnis memiliki kualitas laba yang lebih tinggi dibandingkan dengan komite audit yang berlatar belakang pendidikan non bisnis

H11:Terdapat perbedaan persepsi tentang kualitas laba antara mahasiswa strata 1 dan mahasiswa magister. 


\section{Metode Penelitian}

Rancangan penelitian yang digunakan adalah penelitian eksperimen. Alasan peneliti menggunakan eksperimen karena tujuan penelitian ini adalah untuk mengetahui dampak dari suatu perlakuan (treatment) yaitu pemberian informasi tentang karakteristik GCG suatu perusahaan terhadap persepsi mahasiswa atas kualitas laba. Eksperimen yang peneliti lakukan dapat dikelompokkan sebagai eksperimen kuasi (semu) dan menggunakan Posttest-only control group design. Asumsi yang digunakan adalah bahwa mahasiswa telah memperoleh pengetahuan tentang tata kelola perusahaan baik formal melalui bangku kuliah dan informal melalui berbagai media informasi. Treatment yang diberikan kepada partisipan adalah memberikan simulasi scenario GCG. Partisipan dibagi menjadi dua kelompok, masing masing kelompok diberikan scenario karakteristik GCG yang kuat dan GCG yang lemah secara random. Perbedaan karakteristik GCG akan berpengaruh terhadap persepsi kualitas laba yaitu kualitas laba. Secara ringkas desain eksperimen dapat diikhtisarkan sebagai berikut:

Tabel 2 Rancangan ekperimen 2 x 1

\begin{tabular}{|l|l|}
\hline Keterangan & Kualitas Laba (Y1) \\
\hline GCG Kuat (X1) & $\mathrm{X} 1 \mathrm{Y} 1$ \\
\hline GCG Lemah (X2) & $\mathrm{X} 2 \mathrm{Y} 1$ \\
\hline
\end{tabular}

Populasi adalah mahasiswa akuntansi dan bisnis di Indonesia Strata 1 dan Strata 2 (Magister). Sampel dipilih dengan menggunakan area random sampling. Pada tahap pertama dipilih secara random ibu kota provinsi di Indonesia, kemudian di masing masing kota dipilih random berdasarkan institusi pendidikan yang telah dipilih. Area sampling yang telah dipilih secara random adalah Aceh, Medan, Lampung, Jakarta, Bandung, Yogyakarta, Surabaya, Pontianak, Menado, Makasar, Ambon dan Jayapura.

Metode analisis yang dugunakan adalah uji independent sample $t$ test. Dengan pertimbangan bahwa penelitian ini menguji perbedaan persepsi kualitas laba antara entitas yang memiliki kualitas tata kelola yang baik atau kuat dengan lemah untuk masisng masing skenario yang independen.

\section{Analisis dan Pembahasan}

Jumlah partisipan dalam riset ini adalah 278 orang yang berasal dari berbagai wilayah provinsi di Indonesia. Profil responden disajikan dalam Table 3.

Tabel 3 Profil responden berdasarkan status pendidikan

\begin{tabular}{|l|l|ll|}
\hline Status Mahasiswa & Jumlah & $\%$ & \\
\hline Strata 1 & 200 & 71 & \\
\hline Magister & 78 & 29 & \\
\hline Total Partisipan & 278 & & 100 \\
\hline
\end{tabular}

Responden terbanyak berasal dari mahasiswa strata 1 yang berasal dari berbagai universitas di Indonesia yang berasal dari Universitas negri dan Swasta antara lain: Universitas Sumatera Utara, Universitas Indonesia, Universitas Tri Sakti, Universitas Mercu Buana, Universitas Gadjah Mada, Universitas Brawijaya, Universitas Veteran Surabaya, Universitas Patimura, Universitas Samratulangi, Universitas Tanjungpura, Universitas Muhamadiyah 
Makasar. Sebagian responden tidak menyebutkan asal institusi pendidikan atau universitas karena merupakan pilihan untuk mengisi atau tidak mengisi asal institusi.

\subsection{Uji Hipotesis - Independent Sample T Test}

Sesuai dengan hipotesis yang diajukan maka berikut dasajikan hasil uji hipotesis dengan menggunakan independent sample t test.

\section{Independensi Dewan Komisaris dan Kualitas laba}

Menurut POJK NO. 33 / PJOK.04 / 2014 pasal 20, tentang Direksi dan Dewan Komisaris Emiten atau perusahaan publik menyebutkan bahwa dalam hal Dewan Komisaris terdiri lebih dari 2 (dua) orang anggota Dewan Komisaris, jumlah Komisaris Independen wajib paling kurang 30\% (tiga puluh persen) dari jumlah seluruh anggota Dewan Komisaris. Dewan komsaris mempunyai independensi kuat jika jumlah komisaris independen lebih besar dari 30\%, dan sebaliknya jika kurang kurang maka dikategorikan lemah. Skenario A mencerminkan kondisi independensi komisaris lemah dan scenario B adalah independensi kuat. Tabel 4 meyajikan mean skor persepsi mahasiswa terhadap kualitas laba berdasarkan independensi komisaris. Jumlah partisipan untuk masing masing scenario tidak sama karena ada partisipan yang tidak memberikan skor pada scenario. Misal untuk scenario A, yang memberikan penilaian atas kualitas laba adalah 6,497 partisipan $(n=163)$ dan yang memberikan penilaian. Jumlah partisipan untuk scenario B lebih sedikit karena jumlah yang merespon atas kuesioner yang disampaikan lebih sedikit yaitu 115 .

Tabel 4. Independensi komisaris dan kualitas laba

\begin{tabular}{|c|c|c|}
\hline \multirow[t]{2}{*}{ Skenario } & \multicolumn{2}{|c|}{$\begin{array}{l}\text { Persepsi } \\
\text { Kualitas laba }\end{array}$} \\
\hline & Mean & Sig \\
\hline $\begin{array}{l}\text { Skenario A (Independensi Lemah) } \\
\text { PT. Artha, Tbk memiliki } 5 \text { orang komisaris dari } \\
\text { dalam perusahaan dan } 1 \text { orang komisaris dari } \\
\text { luar perusahaan }\end{array}$ & $\begin{array}{l}6,497 \\
(n=163)\end{array}$ & \multirow{2}{*}{0.031} \\
\hline $\begin{array}{l}\text { Skenario B ( Independensi Kuat) } \\
\text { PT. Aura, Tbk memiliki } 4 \text { orang komisaris dari } \\
\text { dalam perusahaan dan } 3 \text { orang komisaris dari } \\
\text { luar perusahaan. }\end{array}$ & $\begin{array}{l}7,035 \\
(\mathrm{n}=115)\end{array}$ & \\
\hline
\end{tabular}

Berdasarkan tabel diatas menunjukan bahwa skor kualitas laba pada perusahaan dengan karakteristik independensi dewan komisaris kuat lebih tinggi yaitu mean skor adalah 7,035 dibandingkan dengan independensi dewan komisaris lemah yang hanya meraih mean skor 6,497. Perbedaan mean skor dan signifikansi pada tabel 4 diatas bermakna bahwa secara empiris 
mahasiswa mempersepsikan independensi komisaris berpengaruh signifikan terhadap kualitas laba. Hal ini sesuai dengan pemahaman mahasiswa tentang teori agensi bahwa semakin kuat pengawasan yang dilakukan oleh komisaris independen maka kualitas laba akan lebih bagus.

\section{Independensi Komite Audit dan Kualitas laba}

Peraturan Otoritas Jasa Keuangan Nomor 55/POJK.04/2015 tanggal 29 Desember 2015 tentang Pembentukan dan Pedoman Pelaksanaan Kerja Komite Audit serta Keputusan ketua Badan Pengawas Pasar Modal dan Lembaga Keuangan No. KEP-643/BL/2012 tentang pembentukan Komite Audit menyebutkan bahwa anggota Komite Audit Perusahaan dipilih oleh Dewan Komisaris salah satu anggotanya komisaris independen. Komite Audit paling kurang terdiri dari 3 (tiga) orang anggota yang berasal dari Komisaris Independen dan Pihak dari luar Emiten atau Perusahaan Publik.

Tabel 5. Independensi Komite Audit dan kualitas laba

\begin{tabular}{|l|l|l|}
\hline \multirow{2}{*}{ Skenario } & \multicolumn{2}{l|}{$\begin{array}{l}\text { Persepsi } \\
\text { Kualitas laba }\end{array}$} \\
\cline { 2 - 3 } & Mean & Sig \\
\hline $\begin{array}{l}\text { Skenario A (Independensi Komite Kuat) } \\
\text { PT. Danona, Tbk memiliki 1 orang komite audit yang } \\
\text { berasal dari dalam perusahaan dan 2 orang komite audit } \\
\text { dari luar perusahaan }\end{array}$ & $\begin{array}{l}7,306 \\
(\mathrm{n}=163)\end{array}$ & \multirow{2}{*}{0.000} \\
\hline $\begin{array}{l}\text { Skenario B (Independensi Komite Lemah) } \\
\text { PT. Delta, Tbk memiliki 3 orang komite audit yang } \\
\text { berasal dari dalam perusahaan dan 1 orang komite audit } \\
\text { dari luar perusahaan. }\end{array}$ & $\begin{array}{l}6,287 \\
(\mathrm{n}=115)\end{array}$ & \\
\hline
\end{tabular}

Skenario A mencerminkan independensi komite audit kuat dan scenario B mencerminkan independensi komite audit lemah. Skor mean kualitas laba pada perusahaan dengan karakteristik independensi komite audit kuat lebih tinggi yaitu dengan mean skor adalah 7,306 dibandingkan dengan yang lemah hanya meraih skor 6,287. Hal ini bermakna bahwa secara empiris terbukti bahwa mahasiswa mempersepsikan komite audit berpengaruh signifikan terhadap kualitas laba. Pemahaman Mahasiswa tentang komite audit independen dapat mendorong kualitas laba dan meningkatkan keinformatifan laporan keuangan (Hundal, 2013)(12). Hasil penelitian ini sejalan dengan Al-Sayed (2013)(13) yang mengatakan bahwa komite audit yang kuat akan menghasilkan penilaian yang baik pada kualitas laba. Seluruh anggota Komite Audit menghadiri pertemuan intensif yang dijadwalkan sekali setiap kuartal (4 kali setahun) untuk mengkaji keefektifan fungsi audit internal, penerapan audit oleh auditor eksternal, mengkaji seluruh laporan keuangan serta melakukan evaluasi efektifitas pengendalian internal. 


\section{Komisaris Utama dan Kualitas laba}

Menurut POJK NO. 33 / PJOK.04 / 2014 pasal 20, tentang Direksi dan Dewan Komisaris Emiten atau perusahaan publik menyebutkan bahwa dalam hal Dewan Komisaris terdiri lebih dari 2 (dua) orang anggota Dewan Komisaris, jumlah Komisaris Independen wajib paling kurang 30\% (tiga puluh persen) dari jumlah seluruh anggota Dewan Komisaris. 1 (satu) di antara anggota Dewan Komisaris diangkat menjadi komisaris utama atau presiden komisaris. Dewan Komisaris paling kurang terdiri dari 2 (dua) orang anggota Dewan Komisaris Komisaris utama yang berasal dari komisaris independen dinilai mempunyai kemampuan mengendalikan perusahaan dengan lebih obyektif. Sebaliknya jika komisaris utama berasal dari founder atau keluarga maka memberikan persepsi obyektivitas yang lebih rendah.

Tabel 6. Komisaris Utama dan kualitas laba

\begin{tabular}{|l|l|l|}
\hline Skenario & \multicolumn{2}{l|}{$\begin{array}{l}\text { Persepsi } \\
\text { Kualitas laba }\end{array}$} \\
\cline { 2 - 3 } & Mean & Sig \\
\hline $\begin{array}{l}\text { Skenario A (Independensi Kuat) } \\
\begin{array}{l}\text { PT. Era,Tbk memiliki dewan komisaris } \\
\text { utama yang berasal dari komisaris } \\
\text { independen }\end{array}\end{array}$ & \multirow{2}{*}{0.02} \\
$(\mathrm{n}=163)$ & \\
\hline $\begin{array}{l}\text { Skenario B (Independensi Lemah) } \\
\text { PT. Errow Tbk memiliki dewan komisaris } \\
\text { utama yang berasal dari komisaris dalam } \\
\text { perusahaan (pendiri atau keluarga) }\end{array}$ & $\begin{array}{l}\text { (n=115) } \\
\text { (n) }\end{array}$ & \\
\hline
\end{tabular}

Pada Tabel 6 diatas menunjukan bahwa skor mean kualitas laba pada perusahaan dengan karakteristik komisaris utama yang berasal dari komisaris independen (scenario A) sebesar 7,65, lebih tinggi dibandingkan dengan komisaris utama berasal dari dalam perusahaan (pendiri atau keluarga) (scenario B) yaitu sebesar 5,713. Hal ini bermakna bahwa secara empiris terbukti mahasiswa mempersepsikan komisaris utama yang berasal dari komisaris independen berpengaruh signifikan terhadap kualitas laba. Dengan adanya komisaris utama yang independen, maka informasi laporan keuangan yang dihasilkan perusahaan lebih berkualitas sehingga dapat dipergunakan oleh pihak yang berkepentingan untuk mengambil keputusan. Hal ini sejalan dengan penelitian Anderson et al.(2003)(14) yang menyatakan bahwa komposisi dewan komisaris diperusahaan mempengaruhi persepsi investor atas transparansi laporan keuangan.

\section{Aktivitas komisaris dan komite audit terjadwal dan Kualitas laba}

Sesuai Peraturan Otoritas Jasa Keuangan (POJK) No.33/ POJK.04 / 2014, Pasal 16 dan Pasal 31, tanggal 8 Desember 2014, mengenai Direksi dan Dewan Komisaris Emiten atau Perusahaan Publik, Direksi wajib mengadakan rapat gabungan berkala dengan Dewan Komisaris setidaknya satu kali setiap 4 (empat) bulan. Ketentuan mengenai penjadwalan rapat dan penyampaian bahan rapat Direksi sebagaimana dimaksud dalam Pasal 17 mutatis mutandis 
berlaku bagi rapat Dewan Komisaris. Aktivitas rapat dewan komisaris dan komite audit yang terjadwal dan diketahui bersama dianggap mempunyai komitmen dalam membangun tata kelola yang baik. Sebaliknya jika tidak ada jadwal yang jelas maka dipersepsikan komitmen tata kelola lebih rendah.

Tabel 7. Aktivitas rapat komisaris dan komite audit

\begin{tabular}{|l|l|l|}
\hline \multirow{2}{*}{ Skenario } & \multicolumn{2}{l|}{$\begin{array}{l}\text { Persepsi } \\
\text { Kualitas laba } \\
\text { (mean skor) }\end{array}$} \\
\cline { 2 - 3 } & Mean & Sig \\
\hline $\begin{array}{l}\text { Skenario A (Komitmen GCG Rendah) } \\
\text { Komisaris dan komite audit PT. Friser, Tbk tidak } \\
\text { mempunyai agenda rapat yang terjadwal, rapat } \\
\text { disesuaikan dengan kebutuhan. }\end{array}$ & $\begin{array}{l}6,166 \\
(\mathrm{n}=163)\end{array}$ & \\
\hline $\begin{array}{l}\text { Skenario B (Komitmen GCG Tinggi) } \\
\text { Komisaris dan komite audit PT. Flora , Tbk } \\
\text { mempunyai agenda rapat yang terjadwal dan } \\
\text { diketahui bersama jadwalnya. }\end{array}$ & $\begin{array}{l}\text { (n=115) } \\
(\mathrm{n}=0.513\end{array}$ \\
\hline
\end{tabular}

Berdasarkan tabel 7. Perusahaan dengan aktivitas komisaris dan komite audit yang terjadwal (skenario B) memiliki kualitas laba 7,513 lebih tinggi dibandingkan dengan yang tidak memiliki aktivitas terjadwal (scenario B) skor 6,166. Perbedaan mean skor tersebut sangat signifikan. Hal ini menunjukan bahwa secara empiris terbukti mahasiswa mempersepsikan aktivitas komisrais dan komite audit yang terjadwal berpengaruh signifikan terhadap kualitas laba. Persepsi mahasiswa menandakan bahwa aktivitas dewan komisaris yang lebih banyak dan terjadwal secara rutin diapresiasi oleh investor sebagai bentuk komitmen kuat dan control yang baik. Hal ini mencerminkan bahwa prakitk Good Corporate Governance (GCG) didalam perusahaan tersebut telah berjalan dengan baik.

\section{Tingkat kehadiran komisaris dan Kualitas laba}

Sesuai Peraturan Otoritas Jasa Keuangan (POJK) No.33/ POJK.04 / 2014, pasal 31 tentang rapat dewan komisaris. Kehadiran anggota Dewan Komisaris dalam rapat sebagaimana dimaksud pada ayat (1) dan ayat (3) wajib diungkapkan dalam laporan tahunan Emiten atau Perusahaan Publik. Komisaris yang mempunyai kesediaan hadir dalam rapat secara rutin 
menunjukkan adanya komitmen dalam tata kelola perusahaan yang baik, demikian juga sebaliknya.

Tabel 8. Tingkat kehadiran komisaris dan Kualitas Laba

\begin{tabular}{|l|l|l|}
\hline \multicolumn{2}{|l|}{} & \multicolumn{2}{|l|}{$\begin{array}{l}\text { Persepsi } \\
\text { Kualitas laba } \\
\text { (mean skor) }\end{array}$} \\
\cline { 2 - 3 } Skenario & Mean & Sig \\
\hline $\begin{array}{l}\text { Skenario A (Komitmen GCG Tinggi) } \\
\begin{array}{l}\text { Tingkat kehadiran dewan komisaris PT.Hydro., } \\
\text { Tbk dalam rapat relative tinggi (lebih dari 75\% } \\
\text { kehadiran) }\end{array}\end{array}$ & $\begin{array}{l}7,562 \\
(\mathrm{n}=162)\end{array}$ & \multirow{2}{*}{0.006} \\
\hline $\begin{array}{l}\text { Skenario B (Komitmen GCG Rendah) } \\
\text { Tingkat kehadiran dewan komisaris PT.Hendry., } \\
\text { Tbk dalam rapat relatif rendah (kurang dari 60\% } \\
\text { kehadiran ) }\end{array}$ & $\begin{array}{l}5,452 \\
(\mathrm{n}=115)\end{array}$ & \\
\hline
\end{tabular}

Mengacu pada Tabel 8, skor kualitas laba pada perusahaan dengan tingkat kehadiran komisaris yang tinggi dalam rapat memiliki kualitas laba yang lebih tinggi dibandingkan dengan yang rendah tingkat kehadirannya. Dimana untuk skenario A mempunyai tingkat kehadiran yang tinggi dengan mean skor adalah 7,562 dibandingkan dengan skenario B mempunyai tingkat kehadiran yang rendah hanya meraih skor 5,452. Perbedaan mean skor tersebut sangat signifikan. Hal ini bermakna bahwa secara empiris terbukti bahwa mahasiswa mempersepsikan tingkat kehadiran komisaris yang tinggi berpengaruh signifikan terhadap kualitas laba. Berdasarkan persepi tersebut di simpulkan bahwa semakin sering dewan komisaris menghadiri rapat maka diharapkan tindakan pengawasan yang dilakukan oleh dewan komisaris dapat semakin baik, sehingga dewan komisaris dapat mengevaluasi kebijakan yang telah diambil oleh dewan direksi (Chen et al: 2007)(15). Apabila kebijakan dari dewan direksi tidak menguntungkan kepada invenstor maka kebijakan tersebut akan di evaluasi ulang oleh dewan komisaris, dengan aktivitas tersebut diharapkan GCG pada perusahaan berjalan dengan baik.

\section{Frekuensi rapat dewan komisaris dan Kualitas laba}

Peraturan Otoritas Jasa Keuangan (POJK) No.33/ POJK.04 / 2014, Pasal 31, tanggal 8 Desember 2014, mengenai Direksi dan Dewan Komisaris Emiten atau Perusahaan Publik, Dewan Komisaris wajib mengadakan rapat berkala 1 (satu) kali dalam setiap 2 (dua) bulan. Selain itu, Dewan Komisaris dapat mengadakan rapat setiap saat bilamana dipandang perlu oleh Presiden Komisaris atau 2 (dua) atau lebih anggota Dewan Komisaris atau atas permintaan dari 1 (satu) pemegang saham atau lebih yang bersama sama mewakili sedikitnya 1/10 
(sepersepuluh) bagian dari jumlah seluruh saham dengan hak suara yang sah. Frekuensi rapat yang tinggi mencerminkan komitmen dewan komisaris yang tinggi terhadap tata kelola perusahaan.

Tabel 9. Frekuensi rapat dewan komisaris dan Kualitas Laba

\begin{tabular}{|l|l|l|}
\hline Skenario & \multicolumn{1}{|l|}{$\begin{array}{l}\text { Persepsi } \\
\text { Kualitas laba } \\
\text { (mean skor) }\end{array}$} \\
\cline { 2 - 2 } & Mean & Sig \\
\hline $\begin{array}{l}\text { Skenario A (Komitmen GCG Rendah) } \\
\text { Frekuensi Rapat Komisaris rendah (kurang dari } \\
\text { 6 kali setahun) }\end{array}$ & $\begin{array}{l}6,257 \\
(\mathrm{n}=159)\end{array}$ & \\
\hline $\begin{array}{l}\text { Skenario B (Komitmen GCG Tinggi) } \\
\text { Frekuensi Rapat Komisaris tinggi (lebih dari } 8 \\
\text { kali setahun) }\end{array}$ & $\begin{array}{l}7,0435 \\
(\mathrm{n}=115)\end{array}$ & \\
\hline
\end{tabular}

Pada Tabel 9 diatas menunjukan bahwa dewan komisaris berdasarkan pada skenario B melakukan rapat dengan frekuensi lebih banyak sehingga memiliki kualitas laba yang lebih tinggi dengan skor mean 7,0435. Dibandingkan dengan skenario A frekuensi rapat dewan komisaris lebih sedikit dengan skor mean 6,257. Perbedaan mean skor tersebut sangat signifikan. Secara empiris terbukti mahasiswa mempersepsikan frekuensi rapat dewan komisaris berpengaruh signifikan terhadap kualitas laba. Rapat dewan komisaris dapat digunakan untuk menilai efektivitas dewan komisaris dalam melaksanakan pengawasan dan pengendalian. Rapat dewan komisaris merupakan media komunikasi dan koordinasi antara anggota-anggota dewan komisaris dalam melaksanakan tugasnya sebagai pengawas manajemen. Pada hasil tersebut persepsi mahasiswa sejalan dengan penelitian Chen et al., (2006)(15) yang menyatakan bahwa dewan komisaris yang lebih sering mengadakan pertemuan dapat mengurangi kemungkinan terjadinya kecurangan, karena pertemuan yang rutin memungkinkan dewan untuk mengidentifikasi dan menyelesaikan masalah potensial, terutama yang terkait dengan kualitas laba. Dengan demikian hasil dari persepsi mahasiswa menunjukan aktivitas GCG pada perusahaan tersebut telah berjalan dengan baik.

\section{Komisaris independen yang berlatar belakang pendidikan bisnis dan Kualitas laba.}

POJK NO. 33/POJK.04/2014 tentang direksi dan dewan komisaris pasal 4 mengenai syarat menjadi komisaris independen yaitu salah satunya memiliki pengetahuan dan/atau keahlian di bidang yang dibutuhkan Emiten atau Perusahaan Publik. Meskipun tidak secara spesifik dikatakan berlatang belakang pendidikan bisnis, namun pengalaman pendidikan komisaris independen bisa mempunyai efek pada pola managerial dan leadership. Oleh karena itu perlu dikaji apakah mahasiswa memberikan persepsi yang berbeda atas latar belakang pendidikan komisaris.

Tabel 10. Latar belakang pendidikan Komisaris independen dan Kualitas laba 


\begin{tabular}{|l|l|l|}
\hline \multirow{2}{*}{ Skenario } & $\begin{array}{l}\text { Peersepsi } \\
\text { Kualitas laba } \\
\text { (mean skor) }\end{array}$ \\
\cline { 2 - 3 } & Mean & Sig \\
\hline $\begin{array}{l}\text { Skenario A Independen } \\
\begin{array}{l}\text { Komisaris } \\
\text { Pendidikan Non-Bisnis }\end{array}\end{array}$ & $\begin{array}{l}5,812 \\
(\mathrm{n}=163)\end{array}$ & \\
\hline $\begin{array}{l}\text { Skenario B Independen } \\
\text { Komisaris } \\
\text { Pendidikan Bisnis }\end{array}$ & $\begin{array}{l}7,756 \\
(\mathrm{n}=115)\end{array}$ \\
\hline
\end{tabular}

Berdasarkan pada Tabel 10 diatas menunjukan bahwa partisipan mempersepsikan komisaris independen yang berlatar belakang pendidikan bisnis lebih berorientasi pada kualitas laba dan transparan dibandingkan dengan komisaris independen yang berlatar belakang pendidikan non bisnis. Komisaris yang berlatar belakang pendidikan bisnis pada skenario B memperoleh skor kualitas laba dengan mean 7,756. Di sisi lain komisaris independen yang berlatar belakang pendidikan non-bisnis hanya meraih skor kualitas laba 5,812. Dengan demikian secara empiris terbukti bahwa mahasiswa mempersepsikan komisaris independen yang berlatar belakang pendidikan bisnis berpengaruh signifikan terhadap kualitas laba. Komisaris yang mempunyai latar belakang pendidikan bisnis dan mempunyai pengalaman bisnis merupakan dewan komisaris yang mempunyai kompetensi yang tinggi. Dewan komisaris yang memiliki kompetensi tinggi dipersespsikan oleh mahasiswa mempunyai kualitas laba yang lebih tinggi. Persepsi mahasiswa tersebut sejalan dengan penelitian (Antonia, 2008)(16) yang menunjukkan bahwa semakin kompeten dewan komisaris maka akan semakin mengurangi kemungkinan kecurangan dalam pelaporan keuangan sehingga kualitas laba perusahaan menjadi baik.

\section{Proporsi dewan komisaris yang berlatar belakang pendidikan bisnis dan Kualitas laba.}

Pedoman Good Corporate Governance yang dikeluarkan oleh Komite Nasional kebijakan Governance tahun 2011, salah satunya berbunyi anggota Dewan Komisaris harus memenuhi syarat kemampuan dan integritas sehingga pelaksanaan fungsi pengawasan dan pemberian nasihat untuk kepentingan Perusahaan dapat dilaksanakan dengan baik. Oleh karena itu proporsi dewan komisaris yang berlatar belakang pendidikan bisnis yang tinggi memberikan nilai lebih pada aspek fungsi pengawasan dan pengendalian yang menjadi tugas dewan komisaris.

Tabel 11. Proporsi dewan komisaris yang berlatar belakang pendidikan bisnis dan kualitas laba

\begin{tabular}{|l|l|l|}
\hline \multirow{2}{*}{ Skenario } & \multicolumn{2}{|l|}{$\begin{array}{l}\text { Persepsi } \\
\text { Kualitas laba } \\
\text { (mean skor) }\end{array}$} \\
\cline { 2 - 3 } & Mean & Sig \\
\hline $\begin{array}{l}\text { Skenario A } \\
\text { Proporsi Dewan Komisaris mayoritas Pendidikan Bisnis }\end{array}$ & $\begin{array}{l}7,552 \\
(\mathrm{n}=163)\end{array}$ & \multirow{2}{*}{0,01} \\
\hline $\begin{array}{l}\text { Skenario B } \\
\text { Proporsi Dewan Komisaris mayoritas Pendidikan Non-Bisnis }\end{array}$ & $\begin{array}{l}5,765 \\
(\mathrm{n}=115)\end{array}$ & \\
\hline
\end{tabular}


Pada Tabel 11 diatas dijelaskan bahwa partisipan mempersepsikan perusahaan dengan proporsi dewan komisaris yang memiliki latar belakang bisnis yang relative tinggi berorientasi pada peningkatan kualitas laba perusahaan dibandingkan dengan proporsi dewan komisaris yang berlatar belakang pendidikan non bisnis. Komisaris yang latar belakang bisnis yang relative tinggi pada skenario A memperoleh skor kualitas laba dengan mean 7,552. Di sisi lain komisaris yang berlatar belakang pendidikan non-bisnis pada skenario B hanya meraih skor kualitas laba 5,765. Perbedaan mean skor antara kedua skenario tersebut menunjukkan ada perbedaan yang signifikan. Hal ini bermakna bahwa secara empiris terbukti bahwa mahasiswa memberikan perhatian yang serius terhadap proporsi dewan komisaris yang memiliki latar belakang bisnis atau non bisnis.

\section{Komite Audit yang berpengalaman dibidang bisnis dan Kualitas laba}

Keputusan Ketua Badan Pengawas Pasar Modal dan Lembaga Keuangan Nomor: KEP-643/BL/2012 Tentang Pembentukan dan Pedoman Pelaksanaan Kerja Komite Audit, salah satu syaratnya adalah wajib memiliki paling kurang satu anggota yang berlatar belakang pendidikan dan keahlian di bidang akuntansi dan/atau keuangan; Komite audit yang memiliki pengalaman bisnis mempunyai kemampuan untuk memahami proses bisnis lebih baik dibandingkan dengan yang belum berpengalaman. Pemahaman terhadap proses bisnis dapat membantu komite audit dalam mengestimasi risiko audit.

Tabel 12.Komite Audit yang berpengalaman dibidang bisnis dan Kualitas laba

\begin{tabular}{|l|l|l|}
\hline \multirow{2}{*}{ Skenario } & $\begin{array}{l}\text { Persepsi } \\
\text { Kualitas laba } \\
\text { (mean skor) }\end{array}$ \\
\cline { 2 - 3 } & Mean & Sig \\
\hline $\begin{array}{l}\text { Skenario A } \\
\text { Komite audit memiliki Pengalaman Bisnis }\end{array}$ & $\begin{array}{l}7,883 \\
(\mathrm{n}=163)\end{array}$ & \multirow{2}{*}{0,002} \\
\hline $\begin{array}{l}\text { Skenario } \\
\text { Komite audit tidak memiliki pengalaman Bisnis }\end{array}$ & $\begin{array}{l}5,478 \\
(\mathrm{n}=115)\end{array}$ & \\
\hline
\end{tabular}

Berdasarkan Tabel 12 diatas komite audit yang lebih berpengalaman dibidang bisnis lebih tinggi kualitas laba dibandingkan dengan komite audit yang belum berpengalaman. Komite audit yang memiliki pengalaman bisnis pada skenario A memperoleh skor kualitas laba dengan mean 7,883. Di sisi lain komite audit yang memiliki pengalaman non-bisnis pada skenario B hanya meraih skor kualitas laba 5,478. Perbedaan tersebut sangat signifikan. Dengan demikian diperoleh bukti empiris bahwa mahasiswa mempersepsikan komite audit harus berpengalaman bisnis. Persepsi mahasiswa sejalan dengan penelitian yang dilakukan oleh Akhtaruddin dan Haron, (2010)(17) yang menunjukkan bahwa komite audit dengan tingkat kompetensi finansial dan bisnis akan berpengaruh signifikan pada kualitas informasi keuangan yang disajikan perusahaan yang pada akhirnya akan meningkatkan kualitas laba perusahaan.

Analisis selanjutnya diperluas dengan mengkaji apakah terdapat perbedaan persepsi antara mahasiswa Strata 1 (Sarjana) dan mahasiswa Magister. Tujuannya adalah untuk 
mengetahui penguasaan konsep GCG yang berdampak pada perbedaan judgement kualitas laba antara Sarjana dan Magister.

Tabel 13. Uji beda antara persepsi kualitas laba mahasiswa Sarjana dan Magister Group Statistics

\begin{tabular}{|c|c|c|c|c|c|}
\hline & Jenjang & $\mathrm{N}$ & Mean & Std. Deviation & Signifikan \\
\hline \multirow{2}{*}{ komisaris independen } & Sarjana & 200 & 6.7800 & 1.57289 & 0.330 \\
\hline & Magister & 78 & 6.5641 & 1.86276 & \\
\hline \multirow{2}{*}{ Komite audit } & Sarjana & 200 & 6.8400 & 1.53499 & \\
\hline & Magister & 78 & 7.0000 & 1.43246 & 0.427 \\
\hline \multirow{2}{*}{ Komisaris utama } & Sarjana & 200 & 6.7950 & 2.03561 & \\
\hline & Magister & 78 & 7.0000 & 1.61968 & 0.417 \\
\hline \multirow{2}{*}{ Agenda rapat } & Sarjana & 200 & 6.9050 & 1.59962 & 0.005 \\
\hline & Magister & 78 & 6.2564 & 1.97014 & \\
\hline \multirow{2}{*}{ Kehadiran rapat } & Sarjana & 199 & 6.5930 & 1.86682 & 0.169 \\
\hline & Magister & 78 & 6.9231 & 1.43037 & \\
\hline \multirow{2}{*}{ Frekuensi rapat } & Sarjana & 197 & 6.7056 & 1.66740 & 0.048 \\
\hline & Magister & 77 & 6.2857 & 1.30643 & \\
\hline \multirow{2}{*}{ Pendidikan Komisaris } & Sarjana & 200 & 6.7950 & 1.95244 & 0.019 \\
\hline & Magister & 78 & 6.1667 & 2.12234 & \\
\hline \multirow{2}{*}{ Proporsi Pendidikan bisnis } & Sarjana & 200 & 6.7850 & 1.88855 & 0.680 \\
\hline & Magister & 78 & 6.8846 & 1.57893 & \\
\hline \multirow{2}{*}{ Pengalaman komite audit } & Sarjana & 200 & 6.8600 & 1.97482 & 0.692 \\
\hline & Magister & 78 & 6.9615 & 1.76136 & \\
\hline
\end{tabular}

Berdasarkan hasil uji perbedaan yang disajikan pada Tabel 13 diperoleh hasil uji bahwa mayoritas tidak ada perbedaan nyata antara penilain kualitas laba antara mahaiswa Sarjana dan Magister. Perbedaan signifikan hanya pada aspek agenda rapat, frekuensi rapat dan pendidikan komisaris yang berlatar belakang bisnis. Mahasiswa Magister cenderung konservatif dalam menilai kualitas laba dikaitkan dengan aspek tersebut. Tidak adanya perbedaan kuat antara mahasiswa strata 1 dengan magister adalah disebabkan mahaiswa Strata 1 yang dipilih sebagai partisipan adalah mahasiswa semester 6 ke atas. Oleh karena itu diduga mahasiswa Strata 1 sudah cukup memperoleh bekal terkait dengan tata kelola perusahaan.

\section{Simpulan}

1. Mahasiswa mampu membedakan dengan jelas karakteristik tata kelola yang baik dan tidak baik.( tata kelola kuat dan lemah)

2. Mahasiswa memberikan skor kualitas laba yang tinggi pada perusahaan yang mempunyai karakteristik tata kelola perusahaan yang baik dan sebaliknya skor kualitas 
laba yang rendah untuk tata kelola perusahaan yang kurang baik. Perbedaan skor antara tata kelola yang baik dan tidak baik adalah signifikan. Dengan demikian mahasiwa Indonesia sudah faham tentang karakteristik tata kelola perusahaan

3. Tidak terdapat perbedaan persepsi kualitas laba antara Mahasiswa strata 1 (Sarjana) dengan mahasiswa magister yang memiliki dewan komisaris kuat, yaitu yang mempunyai karakteristik memiliki sikap independensi, kompeten (memiliki pengalaman bisnis dan atau berlatar belakang pendidikan bisnis/ekonomi).

4. Terdapat perbedaan signifikan antara persepsi mahasiwa Strata 1 dengan Magister dalam hal aspek frekuensi rapat, agenda rapat yang terjadwal dan latar belakang pendidikan bisnis komisaris.

\section{Daftar Pustaka}

1. Solomon, J.F. and Solomon A. Corporate governance and accountability, John Wiley \& Sons, New Jersey. 2014;

2. Chang, J.C. and Sun H. Does the disclosure of corporate governance structures affect firms' earnings quality?. Review of Accounting and Finance. Rev Account Financ. 2010;9(3):212-43.

3. Holder-Webb, L., \& Sharma DS. The effect of governance on credit decisions and perceptions of reporting reliability. Behav Res Account. 2010;22(1):1-20.

4. Chaghadari MF. Corporate Governance and Firm Performance. Int Conf Soc Econ Dev. 2011;

5. Sarbanes-Oxley Act of 2002, Section 302, Section 404.

6. Hashim HA, Devi SS. Institutional Monitoring and Earnings Quality in Malaysia. Procedia - Soc Behav Sci [Internet]. 2012;65(ICIBSoS):419-26. Available from: http://dx.doi.org/10.1016/j.sbspro.2012.11.143

7. Kamarudin KA, Wan Ismail WA, Samsuddin ME. The Influence of CEO Duality on the Relationship between Audit Committee Independence and Earnings Quality. Procedia - Soc Behav Sci [Internet]. 2012;65(ICIBSoS):919-24. Available from: http://dx.doi.org/10.1016/j.sbspro.2012.11.220

8. Gaio, C., \& Raposo CC. Corporate governance and earnings quality: International evidence. ournal Account Financ. 2014;14(3):1-23.

9. Cohen, J., Krishnamoorthy, G., \& Wright A. Corporate governance in the postSarbanes-Oxley era: Auditors' experiences. Contemp Account Res. 2010;27(3):75186.

10. Abbadi SS, Hijazi QF, Al-Rahahleh AS. Corporate governance quality and earnings management: Evidence from Jordan. Australas Accounting, Bus Financ J. 2016;10(2):54-75.

11. Shank, T., Paul Hill, R., \& Stang J. Do investors benefit from good corporate governance? Corp Gov Int J Bus Soc. 2013;13(4):384-96.

12. Hundal S. Independence, Expertise and Experience of Audit Committees: Some Aspects of Indiation Corporate Sector. American International Journal of Social Science, 2(5). Am Int J Soc Sci. 2013;2(5).

13. Ebaid IA-S. Corporate Governance and Investors' Perceptions of Earnings Quality: Egyptian Perspective. Egypt. Int J Tanta Univ. 2013;13(3):261-73.

14. Anderson, R. C., \& Reeb DM. Board composition: Balancing family influence in S\&P 500 firms. Adm Sci Q. 2004;49(2):209-37.

15. Chen R, El Ghoul S, Guedhami O, Wang H. Do state and foreign ownership affect 
investment efficiency? Evidence from privatizations. J Corp Financ. 2017;42:408-21.

16. Antonia E. Analisis Pengaruh Reputasi Auditor, Proporsi Dewan Komisaris Independen,Leverage, Kepemilikan Manajerial dan Proporsi Komite Audit Independen Terhadap Manajemen Laba. 2008;1-77.

17. Akhtaruddin M, Haron H. Board ownership, audit committees' effectiveness, and corporate voluntary disclosures. Asian Rev Account. 2010;18(3):245-59. 